\title{
TATA KELOLA INDUSTRI GULA DI SITUBONDO MASA KOLONIAL DAN KEBIJAKAN PERGULAAN MASA KINI
}

\author{
Abraham Nurcahyo *
}

\begin{abstract}
Abstrak
Industri gula merupakan industri manufaktur yang berorientasi ekspor bermodal asing. Ketika industri gula mengalami masa jaya tahun 1930, ada 179 pabrik gula yang beroperasi. Pada saat krisis ekonomi, agro industri ini paling parah terkena dampaknya. Tata kelola industri gula sejak masa kolonial sampai sekarang tidak terlepas dengan kebijakan pemerintah. Beroperasi maupun ditutupnya pabrik gula di Situbondo pada masa krisis berkait erat dengan manajemen strategi perusahaan. Dalam hal ini mencakup manajemen produksi dan operasional, tenaga kerja, penelitian dan pengembangan, keuangan dan akuntansi serta pemasaran. Keberadaan pabrik gula di Situbondo berdampak terhadap kehidupan sosial ekonomi masyarakatnya. Tidak efisiennya industri gula masa kini, selain rendahnya produksi hablur, juga karena industri gula menghadapi kendala yang tidak kecil. Kebijakan impor gula berpengaruh terhadap kondisi pergulaan nasional serta program revitalisasi pabrik.
\end{abstract}

\section{Kata kunci: Industri Gula, Kolonial, dan Kebijakan}

\section{Pendahuluan}

Industri gula Indonesia berjaya pada tahun 1930. Ketika itu ada 179 pabrik gula yang beroperasi. Produksinya mencapai 3 juta ton, dan ekspor gula sekitar 2.4 juta ton. Seiring dengan kebijakan pemerintah, industri gula yang ada mengalami pasang surut Produksi gula nasional pernah meningkat relatif cepat dalam periode 1980-an. Akan tetapi pada awal 1990-an mengalami hambatan malahan setelah tahun 1994 produksi gula nasional terus menurun.

Elson antara lain mengatakan bahwa industri gula sangat tepat dilaksanakan di pulau Jawa. Oleh karena jumlah penduduknya relatif padat, sehingga sangat memungkinkan terpenuhinya kebutuhan tenaga kerja dalam jumlah besar. Dalam konteks seperti inilah, perkebunan tebu memang sangat sesuai diusahakan di Jawa (R.E. Elson, 1984). Mengingat tenaga kerja dalam jumlah besar, diperlukan untuk pengelolaan

\footnotetext{
* Abraham Nurcahyo adalah Dosen Pendidikan Sejarah IKIP PGRI Madiun; Jl Setiabudi 85 Madiun; email: abrahamnurcahyo@yahoo.co.id.
} 
perkebunan tebu maupun sektor industri gula. Menurut Knight, pembangunan industri gula berhubungan dengan sejumlah faktor kunci, diantaranya berupa kebijakan pemerintah yang tidak hanya menyangkut modal, melainkan juga terjaminnya tanah, buruh serta pemasaran pasca produksi (G.R. Knight, 1993).

Tata kelola industri gula sejak masa kolonial sampai sekarang tidak dapat dipisahkan dengan kebijakan pemerintah. Kebijakan yang dikeluarkan akan berpengaruh dan menentukan dalam pembentukan berbagai realitas ekonomi dan sosial masyarakat. Keberadaan industri gula pada satu sisi dianggap sebagai jembatan yang menghubungkan masyarakat Indonesia dengan ekonomi dunia; memberi keuntungan finansial yang besar, serta membuka kesempatan ekonomi baru. Namun pada sisi lain perkembangan industri gula juga dianggap sebagai kendala bagi diversifikasi ekonomi masyarakat yang lebih luas; sumber penindasan, serta salah satu faktor penting yang menimbulkan kemiskinan struktural. Berkenaan dengan itu, mengkaji industri gula menjadi salah satu hal menarik untuk dilakukan guna merekonstruksi dan menjelaskan realitas masa lalu yang ada.

Argumentasi studi ini adalah industri gula, mengalami pertumbuhan pesat, dan berpengaruh besar bagi negara kolonial. Industri gula juga penting bagi para pemodal besar maupun masyarakat Indonesia masa lalu dan kini. Kajiannya, diharapkan bermanfaat bagi peng- kayaan sejarah ekonomi. Demikian pula akan bermanfaat bagi kita untuk memahami relevansi industri gula Indonesia masa kolonial dengan industri gula saat ini.

\section{Manajemen Pergulaan di Situbondo}

Sebelum dan setelah tahun 1930 kondisi ekonomi industri gula di Situbondo telah berubah. Krisis ekonomi yang melanda dunia pada tahun 1930-an telah mempengaruhinya. Akibat krisis ini industri gula di Hindia Belanda menjadi terganggu. Banyak pabrik gula menghentikan produksinya. Laporan tahunan pabrik gula menunjukkan, ketika itu dilakukan penyusutan luas area tanaman tebu, jumlah produksi, dan jumlah tenaga kerja. Demikian pula neraca perusahaan pergulaan di Situbondo banyak mengalami kerugian. Jika pada tahun 1925, beroperasi 9 pabrik gula (Arsip Verslag 1926:524), maka tahun 1934 tinggal 4 pabrik gula. Akan tetapi, pada tahun 1938, pabrik gula yang beroperasi lagi menjadi 6 buah (Arsip Verslag, 1938: 51-3).

Sebuah asumsi mengatakan, bertahannya pabrik gula terus berproduksi serta ditutupnya pabrik gula pada masa krisis berkait erat dengan manajemen strategi perusahaan. Manajemen strategi dimaksudkan agar organisasi menjadi solid mampu menampilkan kinerja tinggi. Oleh karena organisasi yang berhasil adalah organisasi yang tingkat efektivitas dan produktivitasnya makin lama makin tinggi. Organisasi ber- 
kinerja tinggi memiliki arah jelas untuk dicapai. Manajemennya menyiapkan tenaga berpengetahuan dan berketerampilan tinggi memiliki semangat kewirausahaan. Para manajernya berkomitmen kuat dengan aksi stratejik mendapatkan keuntungan finansial. Hasil yang hendak dicapai perusahaan bersandarkan pada peningkatan efektivitas dan produktivitas (Sondang P. Siagian, 2001:27-29).

Mengacu pemikiran tersebut dilakukan analisis, antara lain produksi dan operasional, tenaga kerja, penelitian dan pengembangan, keuangan dan akuntansi serta pemasaran.

\section{Produksi dan operasional}

Ruang lingkup pembicaraan aspek manajemen produksi dan operasi berhubungan dengan kapasitas produksi; seberapa banyak reparasi pemeliharaan, serta penggantian peralatan selama melakukan produksi dan jadwal produksi. Kelancaran produksi seringkali sulit diprediksi dengan relatif teliti. Dalam keadaan ini diperlukan perencanaan produksi, yakni tingkat strategis dan taktis. Perencanaan strategis berkenaan dengan rancangan sistem produksi; sedangkan perencanaan tingkat taktis berkait dengan pengelolaan sistem produksi yang tengah berjalan (Dennis Lock dan Nigel Farrow, 199:476).

Pada dasarnya kegiatan yang ditangani pabrik gula dapat dibagi dalam dua masa, yakni di Luar Masa Giling (LMG) dan Dalam Masa Giling (DMG). Melalui laporan tahunan pabrik gula di Situbondo terlihat bahwa Dalam Masa Giling pabrik gula tiap tahunnya tidak sama. Begitu pula dengan jam berhenti, prosentase masa istirahat dari masa panen. Dari tahun ke tahun menunjukkan angka yang berbeda. Tentu saja perbedaan ini terjadi tidak lepas dengan manajemen produksi yang diterapkan oleh menajemen pabrik gula waktu itu. Indikasi terlihat dari angka-angka pada tabel 1 di bawah ini (JG ; Jam Giling, KTJI: Kuintal Tebu Jam Istirahat, LMI: Lama Masa Istirahat, GKT/24 J: Giling Kuintal tebu per 24 Jam, GKT/HK: Giling Kuintal Tebu per Hari Kerja).

Tabel 1 : Tabel Proses Produksi

\begin{tabular}{|c|c|c|c|c|c|c|}
\hline Tahun & JG & KTJI & LMI & \% MI & GKT/24J & GKT/HK \\
\hline 1925 & 3.334 & 103 & 344 & 15,40 & 9.748 & 8.445 \\
\hline 1926 & $3.032,50$ & 68,25 & 289,25 & 13,39 & 9.958 & 8.783 \\
\hline 1927 & $3.032,50$ & 160,25 & 139,25 & 10,98 & 11.854 & 10.681 \\
\hline 1928 & 3.300 & 109 & 362 & 14,27 & 13.144 & 11.269 \\
\hline 1929 & 3.200 & 10 & 488 & 15,57 & 13.744 & 11.604 \\
\hline 1930 & 2.951 & 15 & 312 & 12,46 & 14.465 & 12.861 \\
\hline 1931 & 2.629 & 3,50 & 175 & 7,2 & 15.813 & 14.751 \\
\hline 1932 & 3.302 & - & 198 & 6,52 & 14.367 & 13.488 \\
\hline 1933 & 2.595 & 41 & 154 & 8,13 & 15.993 & 14.367 \\
\hline
\end{tabular}




\begin{tabular}{|c|c|c|c|c|c|c|}
\hline Tahun & JG & KTJI & LMI & \% MI & GKT/24J & GKT/HK \\
\hline 1934 & 2.204 & 54 & 110 & 8 & 15.815 & 14.640 \\
\hline
\end{tabular}

Sumber : Naamlooze Vennootschap Suiker Cultuur Maatschappij, Jaarverslag over 1925-1936

Masa giling pabrik gula di Situbando, biasanya mulai bulan Mei dan berakhir bulan September. Tinggi rendahnya hari giling maupun kapasitas giling, umumnya mengikuti jumlah ketersediaan pasokan tebu.
Demikian pula sebaliknya, jika pasokan tebu kurang, maka hari gilingpun menjadi lebih pendek. Lama giling pabrik gula di Situbondo pada tahun 1939 terlihat pada data tabel 2 berikut ini.

Tabel 2: Tabel Masa Giling

\begin{tabular}{|l|l|l|c|}
\hline \multicolumn{1}{|c|}{ Pabrik Gula } & \multicolumn{1}{|c|}{ Mulai } & \multicolumn{1}{c|}{ Sampai } & Hari \\
\hline Asembagus & 21 Juni & 29 Oktober & 131 \\
\hline Panji & 7 Juni & 21 Oktober & 137 \\
\hline Olean & $11 \mathrm{Mei}$ & 11 September & 122 \\
\hline Wringinanom & $15 \mathrm{Juni}$ & 17 Oktober & 125 \\
\hline Prajekan & $14 \mathrm{Juni}$ & 6 Oktober & 114 \\
\hline Tangarang & $14 \mathrm{Juni}$ & 6 Oktober & 114 \\
\hline De Maas & - & - & - \\
\hline Bedadung & $30 \mathrm{Mei}$ & 25 November & 180 \\
\hline Semboro & $30 \mathrm{Mei}$ & 25 November & 180 \\
\hline \multicolumn{1}{|c|}{ Gunungsari } & $30 \mathrm{Mei}$ & 25 November & 180 \\
\hline
\end{tabular}

Sumber : G. Boorberg dan J. Marches, "Statissiken Omirent Den suikerritaanplant Over De Jaren 1939 en 1940", dalam Proefstation Voor De Java-Suikerindustrie Verhandelingen Vor de Leden Jargaang 1940, (Surabaya: H Van ingen,) hlm. 109.

Masa giling pabrik gula di Situbondo dari tahun 1925-1940, umumnya berada di atas 100 hari. Namun pada tahun 1934 dan 1935 PG. Assembagus tidak giling. Tentunya, hal ini berkaitan dengan tidak adanya tebu untuk digiling pada kedua tahun tersebut. Tidak adanya tebu saat itu karena krisis ekonomi melanda dunia, termasuk Hindia Belanda sehingga berpengaruh terhadap kondisi perusahaan gula. Oleh karena itu ada beberapa pabrik gula tidak melakukan penanaman tebu. Dengan diterapkannya strategi manajemen produksi dan operasional perusahaan PG Panji, PG. Olean, PG. Prajekan, PG. Buduan, dan PG. Semboro tetap berproduksi. Gula yang dihasilkan adalah berjenis Raffinade, SHS, HS. 20 h, HS. 16-20, MS. 10-12 dan MS. 8-10 berjumlah 76.797 ton (Arsip C. Sijlmans, 1935 : 75-85). 
Adanya berbagai jenis gula yang dihasilkan itu berhubungan dengan proses pembuatannya. antara lain di kenal proses defikasi, sulfitasi dan karbonatasi. Proses defitasi menghasilkan gula kuning cokelat (HB), sedangkan sulfitasi dan karbonatasi menghasilkan gula putih (SHS) (A.T Birowo, 1992:132). Selain itu terdapat pula beberapa proses modifikasi leburan sulfitasi, sulfi karbonatasi, dan proses sijlman. PG. Assembagus, PG. Panji, PG. Wringinanom, dan PG. Prajekan dalam produksinya telah menerapkan proses defikasi, sedangkan produksi di PG. Semboro berlanjut dengan proses karbonatasi (P.C. Nicola, 1937:406-29).

Selama krisis berlangsung, pabrik gula PG. Assembagus, PG. Panji, PG. Olean, PG. Wringinanom, PG. Prajekan, PG. Buduan, PG. Semboro serta PG. Gunungsari telah panen. (Arsip C. Siljlmans, 75). Akan tetapi pada waktu itu PG. Assembagus, PG. Wringinanom dan PG. Gunungsari tidak giling. Tebunya kemudian dialihkan pada pabrik gula lain. Adanya beberapa pabrik gula ketika itu tetap berproduksi karena telah melakukan merjer dalam satu kelompok bisnis yang sama (Supriyono,1986: 158). Pengoperasian pabrik gula diatur oleh manajemen perusahaan yang sama. Perusahaan gula, umumnya tidak hanya mengelola satu pabrik gula saja, melainkan dua, tiga, empat pabrik gula.

N.V. Handelsvereeniging "Amsterdam" perusahaan pemilik PG. Bedadung, PG. Semboro dan PG.
Gunungsari di daerah Situbondo telah mengelola 15 pabrik gula di Hindia Belanda (Arsip Verslag, 1938:42). Agar dicapai tingkat efisiensi waktu yang tinggi maka selama proses produksi semua peralatan maupun mesinnya diatur dengan ekstra. Secara intensif mesin selalu dikontrol. Perawatan dilakukan agar mesin atau alat produksi memiliki keragaan yang normal. Perawatan dan pengendalian preventif dilakukan oleh bagian instalasi. Mesin maupun ketel untuk produksi didatangkan dari Eropa. Perusahaan pembuat mesin dan ketel pabrik gula antara lain Petry Dereux, Harvey, Werkspoor, Ruston \& Hornsby dan Babcock \& W (Arsip G.J. Schott, 1929:959-60). Kepastian giling tiap pabrik tidak sama, tergantung pada tipe dan banyaknya ketel yang digunakannya. Pada tahun 1929 ketel PG Assembagus 7 buah, PG. Panji 5 buah, PG. Olean 4 buah dan PG. Wringinanom 4 buah. Dengan dioperasikannya ketel berukuran besar maka kemampuan giling perharinya makin meningkat.

Dalam laporan tahunannya, PG Assembagus mencatat jam berhenti masa giling antara lain perbaikan infrastruktur pabrik, reparasi serta penyetelan mesin penggilingan. Jam berhenti akibat gangguan teknis oleh pabrik gula bisa segera diatasi. Oleh karena adanya perpindahan tenaga kerja pemanen serta pesta-pesta desa menimbulkan jam berhenti menjadi bertambah lama (Arsip Jaarverslag, 1925 :7). Demikian pula, kekurangan pasokan tebu untuk diolah, berakibat jam berhenti bertambah lama. 
Sebelum krisis berlangsung, beberapa pabrik gula Situbondo tidak kesulitan produksi. Guna meningkatkan nilai ekspor, pabrik gula telah menerapkan strategi manajemen berupa ekstensifikasi lahan tebu kebeberapa daerah. Fakta ini terlihat dalam Memori Residen Bondowoso A.H. Neys, 25 April 1929. Dalam memori itu dikatakan bahwa selama periode 1925-1929, pabrik-pabrik gula telah memohon ijin perluasan areal tebu sampai pada batas maksimum yang menjadi haknya, dan ijin itu dikabulkan (Sartono Kartodirdjo, 1978:CXXII-CXXIII). Selain itu dilakukan peningkatan kapasitas giling dengan mengoperasikan ketel-ketel baru berukuran lebih besar dengan jumlah yang memadai (Arsip G.J. Scott, 1929:959-60).

Pengoperasian alat-alat ini tentunya dapat mempercepat proses produksi sehingga akan mengurangi lama giling dan penekanan biaya produksi. Namun ketika terjadi krisis ekonomi, strategi manajemen yang dijalankan oleh industri gula di Situbondo berupa pengurangan kapasitas produksi. Akibatnya, lahan tebu yang dikuasai oleh pabrik gula banyak yang menganggur. Ketika krisis berlangsung total luas lahan PG. Assembagus 104 ha, PG.Wringinanom 50 ha, PG. Buduan 47 ha, PG. Semboro 10 ha, PG. Gunungsari 31 ha (Arsip C. Sijlmaans, 1935:75). Selaras dengan pola tanam, ketika itu telah diterapkan sistem glebagan artinya pembudidayaan lahan sesuai dengan giliranya. Tanah yang sebelum-nya ditanami tebu diganti tanaman padi atau palawija. Malahan tidak menutup kemungkinan bahwa lahan yang semula ditanami tebu, kemudian oleh penduduk dialih fungsikan untuk tembakau. Tembakau merupakan pertanian rakyat penting setelah padi dan jagung di Karesidenan Bondowoso, luasnya mencapai 8.000 bau (Sartono Kartodirdjo, 1978:-CXXVI).

\section{Tenaga Kerja dan Upah}

Saat kondisi normal, industri gula di Jawa mempekerjakan sekitar satu juta pekerja musiman dan sekitar 6.000 pekerja tetap pribumi. Ketika krisis melanda industri gula, 800.000 pekerja di PHK, dan lebih dari $3 / 4$ jumlah pekerja tetap diberhentikan. Dalam usaha perkebunan tebu diperlukan biaya dan tenaga kerja yang cukup banyak, ratarata $800 \mathrm{HOK} /$ ha selama kurang lebih 16 bulan (Mubyarto dan Daryanti, 1991:55).

Pentingnya tenaga kerja dalam industri gula adalah sama dengan kebutuhan terhadap lahan. Maka tenaga kerja dijadikan pertimbangan utama pengenalan industri gula di Hindia Belanda. Dengan sistem Reynoso, memanfaatkan tenaga kerja dalam jumlah besar di Jawa. Tenaga kerja itu sudah terlihat dalam pertanian padi yang diusahakan secara intensiif. Melimpahnya tenaga kerja di Jawa dan tidak adanya alternatif peluang kerja selain perkebunan gula membuat perusahaan gula memiliki kekuatan monopsonistik untuk rekruitmen tenaga kerja. 
Kekuatan monopsonistik industri gula merupakan fenomena bahwa tingkat upah pekerja tetap rendah. Diberlakukannya kebijakan upah rendah karena tenaga kerja di Jawa tidak respon secara positif terhadap meningkatnya upah (Loekman Soetrisno, 1980:104).

Mengingat tenaga kerja merupakan faktor produksi yang penting bagi perusahaan, maka perusahaan menentukan manajemen ketenagakerjaan. Berdasarkan sifat hubungan kerja dengan perusahaan, maka status tenaga kerja pada industri gula dapat dibedakan menjadi dua jenis yakni, tenaga kerja tetap dan tidak tetap. Tenaga kerja tetap memiliki hubungan kerja dengan perusahaan untuk jangka waktu yang tidak tentu. Sebaliknya tenaga kerja tidak tetap merupakan tenaga kerja perusahaan untuk jangka waktu tertentu. Tenaga kerja tetap pada industri gula di Situbondo, umumnya dipegang oleh bangsa Belanda. Sebagai tenaga kerja tetap, mereka menduduki posisi penting. Jabatan yang dipegang diantaranya sebagai administratur pabrik gula, kepala akuntan, asisten akuntan, ahli kimia, operator mesin, kepala gudang, kemudian pengawas penimbangan, pengawas pemotongan, pengawas kebun dan asisten pengawas kebun (Arsip Verslag, 1926:35). Tenaga kerja tidak tetap pabrik gula direkrut dari penduduk setempat. Pekerjaannya membuka tanah, menyiapkan penanaman, perawatan tebu sampai tebu siap tebang. Saat musim tebang berlangsung, mereka menyiapkan lahan yang akan ditebang, penebangan tebu, membersihkan tebu dari kotoran, mengangkat tebu ke angkutan sampai ke tempat timbangan. Selanjutnya, ketika pabrik gula giling, mereka mengangkut tebu dari timbangan menuju alat penggiling. Demikian pula di sekitar emplasemen yang menghubungkan dengan penggilingan tebu, serta pekerjaan di pabrik hingga pengangkutan gula.

Dalam industri gula, ada dua jenis kebutuhan sumber daya manusia (A.T. Birowo, 1992:209-10). Pertama, guna memenuhi kebutuhan tenaga baru karena didirikannya industri gula baru atau adanya perluasan atau perlu adanya perpanjangan tenaga. Kedua, berupa peningkatan kemampuan tenaga yang sudah ada. Hal itu dilakukan karena tenaga tersebut akan menduduki jabatan baru; atau karena inovasi di bidang pergulaan; atau karena adanya perubahan manajemen di bidang pergulaan. Peningkatan tenaga kerja dapat berkait dengan kemampuan taknis maupun menejerial. Upaya peningkatan kemampuan tersebut dilakukan melalui pendidikan.

Pada tahun 1931 didirikanlah Yayasan De Suikerschool dan Suikerbond oleh sindikat pabrik gula, aktif melakukan pendidikan pergulaan. Oleh karena terjadi krisis ekonomi, pendidikan tersebut tidak dilaksanakan. Bahkan pada tahun 1932 ujian sindikat ditiadakan. Seiring majunya 
industri gula, dilakukan inovasi di bidang tanaman serta pengolahan gula dan mesin-mesin. Untuk itu pengetahuan dan keahlian para petugas pabrik gula perlu ditingkatkan agar hasil penemuan Proefstation segera tersalur ke pabrikpabrik gula. Setelah dilakukan pembicaraan antara pimpinan industri gula dengan Proefstation Pasuruan, tahun 1931 dilaksanakan kursus penyegar. Lamanya satu bulan, dibuka setiap bulan Januari atau Pebruari. Ada dua macam kursus penyegar yakni bidang tanaman dan teknik kimia / pengolahan (Archief Suikerindustrie, 1931:5-6).

Persyaratan bagi peserta kursus antara lain pernah mengikuti praktek di pabrik gula minimal dua tahun, memiliki dasar yang baik, dan ditentukan oleh direksi pabrik gula. Namun, untuk kursus yang diadakan tahun 1940/1941 dan 1941/1942 dilakukan perubahan materi. Hal ini disesuaikan dengan kebutuhan dan kemajuan teknologi gula. Teknologi gula berkembang pesat sesudah tahun 1936. Peserta kursus tidak hanya berasal dari orang pribumi. Pendidikan dasar para peserta kursus ditingkatkan, yakni lulusan HHS V tahun atau AMS B.

Besarnya upah antara pekerja tetap dengan tidak tetap cukup mencolok. Pada tahun 1925 upah terendah pekerja tetap, misalnya buruh di pabrik sebesar 60 sen (f 0,60 ) per hari, sedangkan untuk pekerja tidak tetap, kuli pembuat jalan kereta api sebesar 41 sen (f 0,41 ) per hari. Besarnya upah setiap tahun terus mengalami penurunan. Pada tahun 1930, upah buruh pabrik turun menjadi 57 sen (f 0,57 ) per hari, dan kuli pembuat jalan kereta api, tetap 41 sen (f 0,41 ) per hari. Lima tahun berikutnya upah buruh turun lagi menjadi 39 sen (f 0,39 ) per hari. Sedangkan untuk kuli pembuat jalan kereta api tinggal sebesar 22 sen (f 0,22 ) per hari (Peter Boomgaard, 1992:119-20). Upah pembantu pengawas kebun bibit tebu f 350 per bulan, masinis pabrik f 400 per bulan, pengawas tanaman f 550 perbulan, pengawas pemotongan $\mathrm{f} 350$ perbulan, ahli kimia f 400 per bulan, kepala gudang f 375 per bulan, akun$\tan \mathrm{f} 650$ per bulan, dan administratur PG Wringinanom f 1000 per bulan (Arsip Verslag, 1926:36). Dari data tersebut terlihat bahwa upah pekerja tetap dan tidak tetap pribumi sangat kecil bila dibandingkan dengan pekerja tetap Belanda.

Kecilnya upah bagi para tenaga kerja merupakan wujud manajemen eksploitatif pabrik gula. Demikian juga dalam sewa tanah, penduduk sebagai pemilik tanah hanya dibayar dengan sewa yang rendah. Pada saat terjadi krisis ekonomi, selain dilakukan peninjauan pembayaran ongkos produksi, berupa upah buruh, sewa tanah, maupun biaya transpor beberapa pabrik gula dimerger (R.A. Supriyanto, 1986:185).

Manajemen pabrik gula Tangerang milik N.V. Cultuur Maatschappij "Prajekan - Tangerang", se- 
dangkan pabrik gula yang lain menghentikan aktivitas produksinya, maka banyak tenaga kerja diberhentikan.

Para buruh pabrik gula umumnya berasal dari Madura dan penduduk di sekitar lokasi pabrik. Selain bekerja sebagai buruh tanam dan tebang, umumnya mereka juga menjadi petani di sawah dan petani garam. Sebagaimana diketahui bahwa mata pencaharian penduduk Madura antara lain sebagai petani, peternak, nelayan dan petani garam (Sartono Kartodirdjo, 1978: CXLVIII -CXLIX). Mereka bekerja di perusahaan garam milik pemerintah Hindia Belanda.

Sebagai perbandingan diketahui bahwa jumlah buruh industri gula Situbondo, berkisar antara 8000 orang. Para buruh pabrik gula ada di distrik Rogojampi kabupaten Banyuwangi tahun 1930an, tercatat 8761 orang, yang berasal dari 26 desa (Arsip Binnenlandsch Bestuur, 1932: Bundel 2464). Oleh karena letak Situbondo dekat pulau Madura, pabrik gula dalam rekruitmen para buruh tetap memperhatikan kebutuhan tenaga kerja industri garam. Sebelum masa giling dimulai, pihak pabrik gula mendatangkan orang-orang dari pulau Madura. Mereka bekerja sebagai tenaga kasar, buruh tanam dan angkut selama giling, bulan Mei hingga Oktober.

Pada tahun 1925-1935, sebelum krisis ekonomi berlangsung, para buruh pabrik gula jauh lebih banyak bila dibandingkan pada saat krisis. Indikasi ini terlihat dari jumlah gaji selama satu tahun, sedangkan ketika krisis jumlah buruh pabrik gula jauh berkurang. Setelah krisis berakhir jumlah buruh meningkat lagi. Akibat krisis ekonomi, banyak pabrik gula ditutup, sehingga banyak pula penduduk yang menganggur.

Adanya kemerosotan ekonomi merupakan pukulan berat bagi buruh tuna kisma maupun pegawai tetap. Beberapa pabrik gula ditutup sehingga menghapus kesempatan kerja bagi ribuan orang. Meski demikian ada pabrik gula yang beroperasi, hanya saja pada tahun 1935, jumlah staf pegawainya berkurang. Sebagian besar gaji pegawai juga turun drastis.

Gambaran upah dan tenaga kerja tercermin pada grafik di bawah ini:

JUMLAH UPAH BURUH INDUSTRI GULA DI SITUBONDO

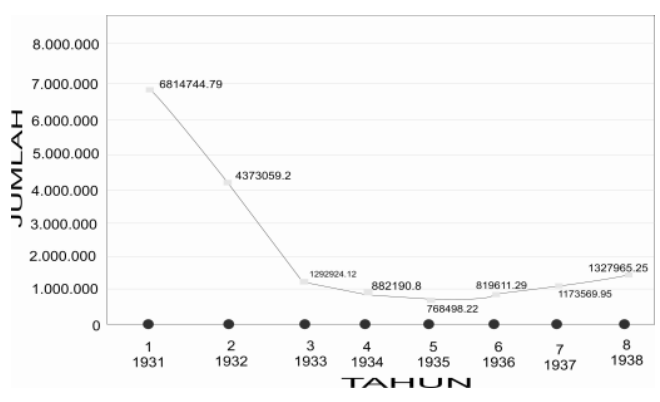

\section{Sumber :}

Verslag Van Het Algemeen Syndicaat Van Suiker Fabrikanten In Ned-Indie Over Het 41e - 44e Vereeningsjaar, 1933 - 1935; 1938. 


\section{JUMLAH PEKERJA INDUSRI GULA DI SITUBONDO}

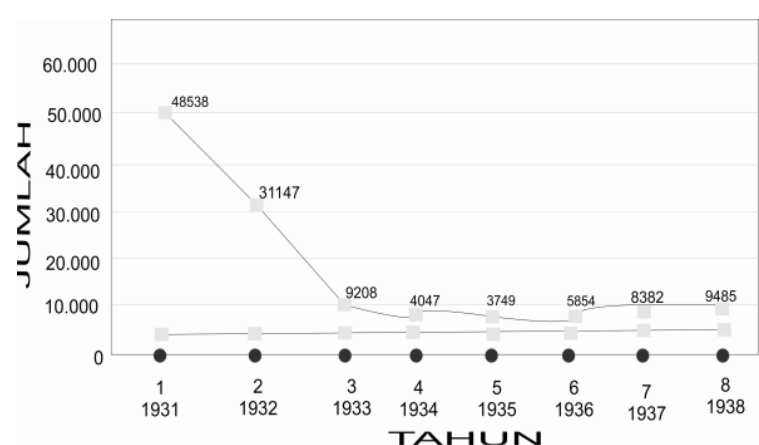

\section{Sumber :}

Diolah Dari Verslag Van Het Algemeen Syndicaat Van Suikerfabrikanten In Ned-Indie Over Het 41e - 44e Vereeningsjaar 1933 - 1935; 1938

\section{Penelitian}

Untuk pengendalian kualitas dan peningkatan produksi, industri gula di Jawa menanam bibit tebu yang bermutu hasil temuan Proefstation. Pada awalnya Proefstation didirikan oleh industriawan gula pada tahun 1886, guna mengatasi krisis serta menanggulangi penyakit sereh. Penyakit ini menyerang perkebunan tebu di Jawa yang mengakibatkan turunnya produktivitas tebu. Berikutnya, tanggal 23 Juli 1886 didirikanlah Proefstation voor Suikeriiet in West Java (Balai Penelitian Gula di Jawa Barat) berpusat di Kagokan Tegal dengan Dr. W. Kruger sebagai Direktur. Pada 22 November 1886 didirikan Het Proefstation Middle Java di Semarang dengan Dr. F. Soltwedel sebagai Direktur. Pada 9 juli 1887 didirikan Het Proefstation Oost Java (POJ) di Pasuruan dengan Dr. J.G. Kramers sebagai Direktur dan J.D. Kous sebagai Deputi Direktur (Hermono Budhisantoso, 1997:3-4).

Guna lebih meningkatkan efisiensi penelitian maka pada Januari 1907 Balai Penelitian Gula di Jawa Barat dan Jawa Timur disatukan menjadi Het Proefstation Voor de Java Suikerindustrie. Bagian Penelitian gula di Pasuruan menjadi bagian Tanaman, kemudian Balai Penelitian Gula di Jawa Barat menjadi Bagian Teknik dan Bagian Kimia. Pada tahun 1919 Bagian Kimia dan Bagian Teknik dipindahkan ke Balai Penelitian gula Jawa Tengah.

Pada awalnya, Proefstation di Pasuruan dikelola oleh seorang Direktur. Akan tetapi, sejak tahun 1926 pengelolanya ditangani oleh direksi (Board of Directors) yang terdiri dari Direktur Bidang Pertanian, Direktur Bidang Kimia dan Direktur Bidang Teknik (Hermono Budhisantoso, 1997:7). Jajaran direksi dipimpin oleh salah satu dari direktur tersebut. Oleh karena adanya krisis lagi di Dunia pergulaan maka sejak tahun 1935 bagian Kimia dan Teknik disatukan menjadi Bagian Kimia dan Teknik. Oleh karena krisis ekonomi dunia pada awal 1932, kegiatan penelitian berkurang sehingga kelompok luasan tebu dikurangi dari 15 menjadi 7 dan pada tahun 1933 tinggal 4 buah, yaitu Pasuruan, Kediri, Yogyakarta dan pantai utara, yaitu Pekalongan, Tegal dan Cirebon. 
Untuk mencegah masuknya penyakit tebu dari luar negeri maka pada tahun 1929 dibangun kebun karantina Ranu Darungan di lereng Gunung Semeru dengan ketinggian kurang lebih 825 M (Hermono Budhisantoso, 1997:9) Hasil utama Proefstation temuan POJ 2878 pada tahun 1921. Varietas ini tidak saja tahan terhadap penyakit mosaik dan sereh, tetapi potensi produktivitasnya lebih tinggi dari pada varietas komersial sebelumnya seperti Cirebon hitam dan POJ 100. Pada tahun 1929, POJ 2878 telah ditanam hingga 90\% areal tebu di Jawa (AT. Birowo, 1992:351; (Hermono
Budhisantoso, 1997:12). Satu tahun kemudian ditemukan POJ 3016. Jenis tebu ini merupakan hasil persilangan POJ 2878 dan POJ 2940. Produktivitas POJ 3016 lebih tinggi dari pada POJ 2878. Varietias ini dalam waktu singkat juga mencapai $90 \%$ areal tebu Jawa. Jenis tebu ini menaikkan produktivitas dari 151,0 ku/ha pada tahun 1928 menjadi 176,3 ku/ha pada tahun 1940 (Mubyarto dan Daryanti 1991:12).

Jenis tebu yang ditanam oleh pabrik gula di Situbondo pada tahun 1940 masing-masing adalah sebagai berikut : (Arsip G. Booberg en J. Marches, 1939 en 1940:124-5).

\begin{tabular}{|l|l|c|r|}
\hline No & Pabrik Gula & Jenis Tebu & Ha \\
\hline 1 & Assembagus & POJ 2878 & 1009,2 \\
\hline & & POJ 2961 & 48,5 \\
\hline & & POJ 2967 & 22,6 \\
\hline 2 & Panji & POJ 2878 & 1010,8 \\
\hline & & POJ 2967 & 70,0 \\
\hline 3 & Olean & POJ 2878 & 366,9 \\
\hline & & POJ 2967 & 327,0 \\
\hline & & POJ 3016 & 2,7 \\
\hline 4 & Wringinanom & POJ 2878 & 547,9 \\
\hline & & POJ 2961 & 19,1 \\
\hline & & POJ 2967 & 243,2 \\
\hline & & POJ 3016 & 24,8 \\
\hline & & POJ 3024 & 0,3 \\
\hline & & POJ 3033 & 0,3 \\
\hline & & POJ 3036 & 13,7 \\
\hline & & POJ 3046 & 0,7 \\
\hline 5 & Prajekan/ Tangarang & POJ 2878 & 138,1 \\
\hline & & POJ 2883 & 274,1 \\
\hline & & POJ 2961 & 148,3 \\
\hline & & POJ 2967 & 145,1 \\
\hline & & POJ 3016 & 128,2 \\
\hline 6 & De Maas & POJ 2878 & 396,9 \\
\hline
\end{tabular}




\begin{tabular}{|l|l|c|r|}
\hline No & Pabrik Gula & Jenis Tebu & Ha \\
\hline & & POJ 2967 & 201,8 \\
\hline & & POJ 3016 & 1,3 \\
\hline 7 & Bedadung & POJ 2878 & 3,6 \\
\hline & & POJ 2967 & 77,7 \\
\hline 8 & Gunungsari & POJ 2967 & 1214,4 \\
\hline & & POJ 3016 & 17,7 \\
\hline
\end{tabular}

Target penelitian Proefstation adalah menciptakan temuan baru, mengembangkan metode baru, dan melakukan terobosan guna memantapkan serta meningkatkan produksi gula. Untuk mencapai sasaran itu, baik sebelum, ketika dan setelah krisis ekonomi berlangsung maka strategi penelitian yang dilakukan oleh lembaga itu antara lain sebagai berikut: (Hermono Budhisantoso, 1997:9-15; AT. Birowo,1992:350).

a. Penemuan varietas tebu unggul baru yang responsif terhadap pemupukan yang tepat, dan tahan terhadap hama penyakit.

b. Pengembangan budidaya tebu yang efisien, pemupukan yang seimbang, perlindungan tanaman, secara terpadu, serta pemanfaatan zat pengatur tumbuh atau pengatur kemasakan secara tepat.

c. Pencarian dan penentuan pola bercocok tanam tebu yang disesuaikan dengan kondisi iklim dan tanah berbagai daerah pengembangan.

d. Penemuan dan pengembangan teknologi pembuatan gula penggunaan alat modern untuk menekan kehilangan gula dalam pasca panen, penghematan energi dan bahanbahan lainya.

e. Pencarian dan penentuan pola bercocok tanam tebu yang disesuaikan dengan kondisi iklim dan tanah berbagai daerah pengembangan.

f. Penemuan dan pengembangan teknologi pembuatan gula penggunaan alat modern untuk menekan kehilangan gula dalam pasca panen, penghematan energi dan bahanbahan lainya.

\section{Keuangan dan Akuntansi}

Berdasarkan sejumlah laporan tahunan pabrik gula di daerah Situbondo diketahui tentang kondisi keuangan perusahaan akhir tahun 1925, perubahan pada tahun 1929, 1930 serta keuangan tahun 1935. Industri gula di Jawa sangat tergantung pada pasar dunia. Fluktuasi harga gula di Amsterdam berpengaruh terhadap kondisi keuangan pabrik gula di Jawa. Pada tahun 1923 harga gula di Amsterdam f 45, kemudian tahun 1929 turun f 12,5, dan tahun 1931 menjadi f 8,125. Sementara itu pada bulan Januari 1932 harga gula ini merosot menjadi $f$ 7,75 dan $\mathrm{f} 5,50$. Akan tetapi harga gula ini tidak bertahan lama, malahan bulan November 1933, merosot menjadi f 4,475 (Arsip H.C. Prinsen Geerligs, 1933-:353). Walaupun harga gula mengalami penurunan, namun produksi gula di Jawa tidak mengalami perubahan yang berarti. Industri gula dilindungi pemerintah 
dengan berbagai kebijakan antara lain mengenai sewa tanah dan tenaga kerja.

Memperhatikan laporan tahunan pabrik gula di daerah Situbondo diketahui bahwa antara tahun 1931-1935 merupakan masa sulit bagi industri gula. Pihak perusahaan mengurangi pembayar an devidennya kepada para pemegang saham. Jika tahun 1930 perusahaan membayar deviden sebesar f 9.880,40 maka pada tahun 1931 deviden yang dibayar sebesar $\mathrm{f}$ $4.412,20$, kemudian pada tahun 1932 deviden turun lagi menjadi $\mathrm{f}$ $3.038,20$. Pembayaran deviden dilakukan melalui cadangan deviden yang terkumpul pada masa sebelumnya (Arsip Jaaverslag, 1930, 1931, 1932).

Walaupun kondisi industri gula kurang menguntungkan, namun di beberapa pabrik melakukan perluasan dan perbaikan prasarana produksi. Perbaikan dan perluasan terhadap instalasi yang sebelumnya tercatat dalam penghitungan beban biaya, kini dianggap sebagai pengeluaran modal. Sementara itu anggaran belanja pada harihari biasa tidak dijumpai lagi. Tahun 1930 rentabilitas merosot dan semakin menurun pada tahun 1931 Sehingga semua perusahaan mengalami kerugian. Kerugian yang dialami PG. Assembagus selama tahun 1930 mencapai f 597.762,57. Jika sebelum tahun 1930 PG. Assembagus mendapat laba, namun tahun 1931, 1932, 1933, pabrik gula tersebut merugi. Bahkan pada tahun 1934 dan 1935 PG. Assembagus tidak berproduksi, dan kembali aktif pada tahun 1936. Akibatnya modal produksi diambilkan dari dana cadangan pada akhir tahun 1935. Dapat dikatakan bahwa tahun 1930an merupakan masa sulit bagi industri gula. Banyak pabrik gula di Situbando menghentikan produksinya.

Kondisi keuangan industri gula pada tahun 1925-1941 diketahui dari neraca perusahaan perkebunan pada masa itu. Neraca merupakan sebuah gambaran singkat mengenai aktiva dan pasiva perusahaan pada hari tertentu, tahun tertentu berupa finansial. Dalam neraca tercatat modal saham, modal pinjaman dan laba yang ditahan. Demikian pula kekayaan berbentuk tanah, gedung, mesin pabrik, persediaan serta uang tunai. Tercatat juga jumlah utang dan piutang perusahaan yang bersangkutan. Dari neraca diketahui kondisi keuangan industri gula di Situbondo, setiap tahunya mengalami fluktuasi. Gambaran neraca pabrik gula di Situbondo antara tahun 1925-1936 sebagai berikut :

\begin{tabular}{|c|c|c|}
\hline Tahun & NV. SCM. & NV. CMW. \\
\hline 1925 & f $2.070 .550,66$ & f $9.652 .310,55$ \\
\hline 1926 & f $8.331 .709,29$ & f $8.930 .742,95$ \\
\hline 1927 & f 8.894 .254 .08 & f $9.507 .852,98$ \\
\hline 1928 & f $8.628 .753,34$ & f $9.853 .867,82$ \\
\hline 1929 & f $8.206 .602,81$ & f $9.344 .235,95$ \\
\hline
\end{tabular}




\begin{tabular}{|c|c|c|}
\hline Tahun & NV. SCM. & NV. CMW. \\
\hline 1930 & f $6.822 .805,56$ & f $8.941 .157,60$ \\
\hline 1931 & f $6.889 .802,88$ & f $9.497 .522,77$ \\
\hline 1932 & f $7.002 .719,09$ & f $6.417 .496,68$ \\
\hline 1933 & f $6.150 .213,14$ & f $6.185 .965,35$ \\
\hline 1934 & f $4.866 .461,88$ & f $4.319 .507,69$ \\
\hline 1935 & f $4.252 .914,73$ & f $4.291 .023,37$ \\
\hline 1936 & f $4.328 .966,76$ & f $3.953 .411,43$ \\
\hline
\end{tabular}

Dana di atas merupakan penerimaan pabrik gula selama satu tahun buku untuk berbagai keperluan perusahaan.

Dalam hal ini untuk menambah sarana kas selama tahun buku, surat berharga telah dijual. Efek yang dimiliki oleh PG. Assembagus antara lain obligasi Belanda, Bank Holland, Benito, saham du Croo dan Brauns, N.V. Cultuur Transport, dan N.V. Philips Omroep Holland-Indie (Arsip Jaarverslag, 1925:20). Selain itu penjualan gula yang telah diproduksi pada tahun itu merupakan sumber utama penerimaan perxusahaan.

Untuk PG. Wringinanom, surat berharga yang dimiliki antara lain adalah saham Nederland 1919, Nederlandsch-indie, 2e Em, Amsterdam 1925, 'S-Gravenhage 1919, Roterdam 1915, H.IJ. S. M. 1900 / 11,SS.1923, Nederlandsch Indische Spoor 1914, Zwitserland, Amersfoort 1925, Gemeente Delft 1925, Hilverwerkpl. Du Croo dan Brauns, Ned.-Indische Gas-Maatschappij 1923, H.V.A. 1918, Deli-Spoor 1918, N.C.S. 1908/12, Semarang-Joana Tram, Semarang-Cheribon Tram 1918, Serajoedal Tram 1899, saham
N.V. Cult. Transport, Oprichtersewijzen, Holland-Huis, Brussel dan Oedaya. Berbagai saham itu dapat dibedakan menjadi lima kelompok yaitu pinjaman pemerintah, pinjaman berbagai kota dan propinsi, kereta api dan jalan tram, bank hipotik, dan lainlain. Pada tahun 1929 saham dari pemerintah berjumlah $f$ 496.700, pinjaman berbagai kota dan propinsi sebesar f 228.000, saham kereta api dan jalan tram $\mathrm{f} 308.100$, dan saham pada bank hipotik f 4000 serta saham lainnya sebanyak f 34.500 (Arsip Naamlooze, 1929: 26-7). Aktiva dalam neraca dipisahkan jadi dua kelompok yaitu aktiva tetap dan aktiva lancar (Dennis Lock dan Nigel Farrow, 1999:116-119). Aktiva tetap merupakan kekayaan yang dimiliki perusahaan, sedangkan aktiva lancar adalah aktiva yang dibeli oleh perusahaan, untuk melaksanakan transaksi jangka pendek. Biasanya aktiva tetap dinilai dengan biaya setelah dikurangi saham pada peruahaan lain.

Pada tahun 19030-an kondisi keuangan dan akuntani pabrik gula di Situbondo relatif baik. Analisis pengluaran dan penerimaan pabrik gula pada tahun itu tercatat seperti di bawah ini: (Arip Jaarverslag, 1930) 


\begin{tabular}{|l|ll|}
\hline Nilai buku perkebunan pabrik gula Assembagus & f & $3.597 .762,57$ \\
\hline Nederlandshe Handel-Maatschappij & f & $166.089,13$ \\
\hline Efek-efek & f & 84.402 \\
\hline
\end{tabular}

Guna menambah kas selama tahun buku, dijual beberapa surat berharga sebagai berikut :

Obligasi Belanda 1917, 4,5 \% nominal Obligasi Belanda 1918, 5 \% nominal Obligasi Belanda 1919, 5 \% nominal Obligasi Hindia Belanda 1917, 5 \% nominal

$\begin{array}{cc}\text { f } & 264.700 \\ \text { f } & 22.500 \\ \text { f } & 12.000 \\ \text { f } & 6.100\end{array}$

Nilai buku per akhir Desember 1930 dari :

\begin{tabular}{|l|c|}
\hline Pemilikan saham yang lain & f $184.225,16$ \\
\hline Nilai saham yang ditaksirkan & f 84.402 \\
\hline Jadi kerugian berjumlah & f $94.823,16$ \\
\hline
\end{tabular}

Dengan ini tercatat $\mathrm{f} 28.908,45$ atas beban obligasi yang mengalami penurunan nilai. Perhitungan ditutup tanpa saldo. Sisa f 70.914,71 dimasukkan pada debet perhitungan untung rugi.
Rekening koran dimuat dengan kurs per akhir Desember 1930. Tercatat dalam rekening Koran resmi perusahaan untuk perdagangan efek. Berkas-berkas yang tidak berjalan di nilai sebagai berikut :

\begin{tabular}{|c|c|}
\hline F 1000 nominal 5\% obligasi Beniso & $\mathrm{f} \quad 1.000$ \\
\hline F 2000 nomnal saham N.V. Jaarbeursgebouw & $\mathrm{f}$ \\
\hline $\begin{array}{l}\text { F } 300 \text { nominal saham N.V. Philips'omroep Holland- } \\
\text { Indie }\end{array}$ & f $\quad 3.000$ \\
\hline $\begin{array}{l}\text { F } 10.000 \text { nominal saham N.V. } \\
\text { Plaatsen V./h. Du Croo dan Brauns }\end{array}$ & P.M. \\
\hline Jumlah & f 4.002 \\
\hline Kas Belanda & $3.089,10$ \\
\hline Kas Assembagus & f $21.005,10$ \\
\hline Gula yang tak terhitung pada tahun 1930 & f $721.714,79$ \\
\hline Debitur & f $153.592,35$ \\
\hline
\end{tabular}

Nilai sejumlah itu merupakan uang muka yang dikeluarkan PG.Sempalwadak kepada tenaga kerja Eropa dan pribumi. 


\begin{tabular}{|l|l|l|}
\hline $\begin{array}{l}\text { Barang-barang dalam gudang merupakan bahan } \\
\text { mentah }\end{array}$ & f $233.679,14$ \\
\hline Barang bergerak & f $135.370,34$ \\
\hline Panen tahun 1931 dan tahun-tahun berikutnya & f $1.672 .258,92$ \\
\hline
\end{tabular}

Penjelasan neraca dalam tahun yang sama untuk posisi kredit sebagai berikut :

\begin{tabular}{|l|l|l|}
\hline Dana cadangan & & f 1.000 .000 \\
\hline Cadangan exstra & & f $971.512,62$ \\
\hline Saldo neraca sebelumnya & f $1.097 .260,05$ & \\
\hline Kerugian tahun buku/1930 & f $125.747,43$ & \\
\hline Saldo akhir 1930 & & f $971.512,62$ \\
\hline & f $1.877 .163,14$ & f $1.524 .364,77$ \\
\hline Saldo neraca lalu & f $352.798,37$ & \\
\hline $\begin{array}{l}\text { Mengeluarkan modal tahun 1930 } \\
\text { demi kepentingan perusahaan }\end{array}$ & f $1.524 .364,77$ & \\
\hline &
\end{tabular}

Cadangan obligasi mengalami penurunan, tercatat demikian :

\begin{tabular}{|l|l|l|l|}
\hline Cadangan untuk pajak & & f $61.658,61$ & \\
\hline $\begin{array}{l}\text { Saldo per akhir tahun } \\
1929\end{array}$ & f 157.279,91 & & \\
\hline $\begin{array}{l}\text { Penafsiran sementara } \\
\text { tahun 1929 }\end{array}$ & f 80.700 & & \\
\hline Surplus tantiemes1921 & f 14.921,30 & & \\
\hline Saldo per akhir 1930 & & f 95.621,30 & \\
\hline $\begin{array}{l}\text { Dana bagi kepentingan } \\
\text { umum }\end{array}$ & f 61.658,61 & f $74.477,27$ \\
\hline Kreditur & & f $159.461,71$ \\
\hline $\begin{array}{l}\text { Pajak untuk pembayaran } \\
\text { deviden }\end{array}$ & & f $19.118,39$ \\
\hline
\end{tabular}

Pos-pos pengeluaran dan pemasukan keuangan pabrik gula tiap tahunnya berubah sesuai dengan kondisi ekonomi.

\begin{tabular}{|l|c|c|c|}
\hline & $\mathbf{1 9 2 9}$ & $\mathbf{1 9 3 3}$ & $\mathbf{1 9 3 6}$ \\
\hline Dana cadangan & 2.000 .000 & 1.477 .205 .89 & 227.646 .15 \\
\hline Dana perusahaan & 2.421 .189 .23 & - & - \\
\hline Cadangan deviden & 336.702 .72 & 149.007 .33 & 149.007 .33 \\
\hline Cadangan pajak & 129.272 .06 & $21.024 .-$ & 21.024. \\
\hline
\end{tabular}


Walaupun pada tahun 1933 pabrik gula tidak memiliki dana perusahaan, namun pabrik gula telah mendapat dana dari Bankiers sebesar f 284.840,05 (Arip NV. Cultuur-Maaatschappij Wonolangan, 1933:19). Laba pabrik gula lebih rendah bila dibandingkan dengan hasil yang dicapai pada tahun 1929 . Untuk itu pada tahun 1933 pabrik gula menggunakan aktivanya lebih intensif dan efektif. Kinerja pabrik gula pada tahun 1933, diupayakan meningkatkan laba bersamaan dengan jumlah produksi yang terus bertambah. Target indutri gula tahun berikutnya meningkatkan laba lebih tinggi daripada tahun sebelumnya. Rasio ini merupakan cara lain dalam memanfaatkan modal yang dipakai. Aktiva yang tidak digunakan tidak masuk aktiva perusahaan.

Ketercukupan dana atau modal perusahaan berpengaruh terhadap struktur keuangan perusahaan. Oleh karena itu pengoperasiannya hendaknya mengacu kondisi keuangan secara keseluruhan. Beberapa faktor yang telah berpengaruh pada sumber modal yang dipakai perusahaan adalah ukuran perusahaan, sifat aktiva, jumlah dan stabilitas laba, dan kondisi yang ada dipasar finansial (Dennis Lock dan Nigel Farrow, 1999:116-119). Dari waktu ke waktu akan terjadi perubahan struktur keuangan. Pada tahun 1930 sampai 1935 struktur keuangan industri gula di Situbondo terjadi perubahan. Oleh karena sebagian kreditur menarik modal yang diinvestasikan pada PG Assembagus maupun PG. Wringinanom. Selain itu karena adanya pembatasan produksi akibat krisis ekonomi.

Dari neraca tahun 1933 tampak bahwa sebagian besar modal yang diperlukan perusahaan berasal dari dana cadangan. Sementara itu untuk modal sendiri berasal dari para pemegang saham. Perusahaan menggunakan hutang jangka panjang dalam jumlah yang terbatas bila dibandingkan untuk kepentingan ekspansi perusahaan pada masa itu. Jumlah seluruh dana yang diperlukan untuk konsolidasi perusahaan pada tahun itu sebesar $\mathrm{f} 2.749 .140,39$ (Arip NV. Cultuur-Maatschappij, 1993 :18). Jumlah penjualan gula pada tahun 1933 senilai f 1.535.177,76 merupakan jumlah yang cukup besar bila dibandingkan dengan dana cadangan pada tahun yang sama yang memiliki oleh PG Wringinanom.

Data di atas menunjukkan, kondisi keuangan industri gula di Situbondo pada tahun 1925-1930 jauh lebih baik, bila dibandingkan dengan tahun 1930-1935 serta antara tahun 1936-1941. Dalam struktur pembiayaan, biaya produksi dan biaya adminitrasi relatif lebih tinggi. Jumlah penerimaan dan pengeluaran dalam arus kas tiap tahun berubah sesuai dengan volume kegiatan tiap bulannya. Perubahan kondisi keuangan industri gula di Situbondo sangat dipengaruhi oleh biaya produksi. Oleh karena fungsi biaya produksi memiliki ciri increasing return of scale yang berarti semakin besar jumlah produksi yang dihasilkan, biaya produksi persatuan akan lebih banyak dapat ditekan (A.T Birowo, 1992:285). Untuk menekan 
biaya produksi maka, dilakukan konsolidasi dalam semua aspek, produksi dan operasi, serta keuangan dan akuntansi.

\section{Pemasaran}

Gula sebagai komoditas ekspor menghasilkan devisa bagi negeri Belanda. Langkah-langkah yang harus ditempuh dalam hubungannya dengan pemasaran gula adalah penetapan produk dan jenis gula yang hendak dipasarkan. Pemasaran produk gula tidak hanya terbatas pada satu jenis. Akan tetapi juga menyangkut variasi produk lainnya. Dalam mengekspor, setiap perusahaan gula terlebih dahulu harus memutuskan banyaknya gula yang akan dipasarkan. Masing-masing pabrik gula menetapkan target ekspor gula sesuai dengan kapasitas produksi tiap tahunnya. Sesuai dengan jenisnya, gula yang diekspor terdiri dari lima macam, yaitu SHS, SSS, HS, Muscovados, MS daan Gecentr Z.S.

Negara-negara pengimpor gula berasal dari berbagai benoa, baik dari Eropa, Asia, Afrika, Amerika dan Austrslia: Inggris, Belanda, Alexandria, Port said, Suez Rusia, India, Srilangka, Cina, Formosa, Hongkong, Jepang, Korea, Penang, Siam, Singapura, Afrika Timur, Mesir, USA, Selandia Baru dan Australia (Anon, 1925:16). Meskipun gula dipasarkan ke berbagai negara, namun dalam penyalurannya, pabrik gula tidak langsung mengirimkannya, melainkan lewat lembaga pemasaran; VISOCO
(Vereeniging Van Java Suiker Ondernemers ter Quottering der Unitvoeren bij Internationale Contract). Selanjutnya pada tanggal 31 Dsember 1932 berdirilah NIVAS (Nederlandsche Indische Vereeniging Voor het Afzet Van suiker) (Arsip AP. Honig, 1940:436).

Perusahaan gula merupakan badan usaha komersial. Untuk itu pertimbangan utama dalam aktivitas perusahaan adalah mengoptimalkan keuntungan. Hal ini berarti bahwa besar atau kecil harga gula akan berpengaruh terhadap tingkat keuntungan yang dapat diperoleh. Dengan harga f 30 per pikul tahun 1920-1921, industri gula di Jawa mendapat keuntungan besar. Perusahaan kemudian melakukan perluasan prasarana produksi, penggantian mesin-mesin yang lebih modern, perluasan lahan tanaman mencapai 150.000 ha pada tahun 1920 dan sampai 195.000 ha pada tahun 1927 serta didirikan pabrik gula baru (Arsip P. Honig, 1940:434). Akan tetapi, laba yang demikian besar dicapai oleh industri gula di Jawa tidak dapat bertahan lama. Penyebabnya, walau produksi gula dunia meningkat pesat, namun tidak sebanding dengan yang dikonsumsi, juga karena adanya autarki sehingga membuat pasar gula jatuh.

Untuk mengatasi lesunya pemasaran gula, negara-negara penghasil gula dunia mengeluarkan kesepakatan bernama Chadbourne. Negara yang tergabung dalam persetujuan ini antara lain Jawa, Cuba, Cekoslowakia, German, Polandia, Hongaria dan Belgia. Deng- 
an adanya persetujuan Chadbourne ini diharapkan dapat memasarkan gula yang masih menumpuk belum terjual. Selain itu dilakukan pengurangan produksi yang berimbang. Masing-masing negara diberi kuota ekspor dari tahun 1931 sampai dengan tahun 1935. Kuota ekspor dari tahun 1931 ditentukan 2.3000 .000 ton, kemudian tiap tahunnya ditambah 100.000 ton sehingga pada tahun 1935, Jawa boleh mengekspor gula dengan jumlah 2.700.000 ton (Arsip P. Honig, 1940:435), namun kuota ekspor itu tidak dapat terpenuhi, malahan tahun 1931 sampai 1935 ekspor gula dari Jawa terus menurun.

Oleh karena gula merupakan komoditas ekspor maka pemasaran gula sangat dipengaruhi oleh kondisi perekonomian dunia. Jatuhnya harga gula dunia dan krisis ekonomi merupakan kendala serius memajukan industri gula. Banyak pabrik gula di Situbondo tidak produksi. Pabrik gula yang pada tahun 1934 masih tetap melakukan aktivitasnya antara lain PG. Panji, PG. Olean, PG. Prajekan, PG.Buduan, dan PG. Semboro dengan total produksi sebesar 76.797 ton (Arsip C. Sijlmans, 1934,1935:85). Sebelum ekspor dilakukan, gula terlebih dahulu ditampung oleh NIVAS, kemudian baru didistribusikan ke negara pembeli lewat pelabuhan Probolinggo. Setiap tahunnya pelabuhan bertambah ramai setelah pabrik gula yang berada di Situbando, Probolinggo, dan Pasuruan beroperasi.
Pemerintah melengkapi fasilitas pelabuhan sehingga pelabuhan Probolinggo menjadi pelabuhan gula ketiga di Jawa setelah Surabaya dan Semarang (Van Der Mandere, 1928:71).

Pemasaran gula oleh industri gula di Situbondo tidak menemui kesulitan karena pemasarannya ditangani oleh NIVAS. Satu diantara berbagai tujuan pemasaran perusahaan adalah untuk memperoleh laba yang optimal. Sesuai dengan sasaran yang diharapkan, perusahaan harus menerapkan strategi yang tepat. Lingkungan pemasaran suatu perusahaan terdiri dari para pelaku dan kekuatan-kekuatan yang berasal dari luar fungsi manajemen pemasaran. Keberhasilan strategi pemasaran yang diterapkan perusahaan tergantung pada analisis dan pengamatan yang cermat. Strategi pemasaran perusahaan terdiri dari pengambilan keputusan tentang biaya pemasaran perusahaan, bauran pemasaran, dan alokasi pemasaran dalam hubungannya dengan keadaan lingkungan.

Strategi pemasaran menyeluruh perusahaan tercermin dalam rencana strategi pemasaran perusahaan yang disusun. Rencana strategi pemasaran perusahaan adalah suatu rencana pemasaran jangka panjang yang bersifat menyeluruh dan strategis (Dennis Lock dan Nigel Farrow, 1999:201-2),

Dalam aktivitas pemasaran, NIVAS tidak bisa lepas dari unsur di atas. Mengenai perantara pemasaran, NIVAS bekerjasama dengan KPM (Koninklijke Paket Vaart Maatschappij) untuk pengiriman gula ke- 
berbagai negara, kemudian dengan bank, NIHB (Nederlands Indische Handelsbank), dan NHM (Nederlands Hendels Maatschappij). Meskipun sering terjadi pro dan kontra mengenai campur tangan pemerintahan dalam pemasaran gula, namun tidak ada kekuatan masyarakat yang menolak keputusan pemerintah membentuk organisasi pemasaran gula yang baru (C. Sijlmans, 1935:435). Malahan Volksraad telah menerima rencana pemerintah. Begitu pula dengan lingkungan makro, tidak dapat dipengaruhi oleh, perilaku dan kinerja dari sistem pemasaran gula. Perusahaan harus menyesuaikan diri. Mengingat, lingkungan makro selalu berubah begitu cepat.

Dalam konteks pemasaran, NIVAS bertindak sebagai pembeli dan penjual. Kebijakan pada periode ini adalah mewajibkan Jawa menurunkan produksi dari 3 juta ton menjadi 1,4 juta ton (Simatupang et.al. 1999:508). Bersamaan dengan itu dibentuk Konvensi Gula Internasional (International Sugar Convention $=I S C$ ) yang menetapkan kuota ekspor gula suatu Negara. NIVAS mewajibkan pabrik gula menjual produknya melalui NIVAS dengan imbalan 1,64 persen dari biaya produksi. Di samping itu NIVAS melakukan penelitian dan pengembangan di Pasuruan dengan biaya dari pabrik sebesar 1,36 persen.

\section{Dampak Pabrik Gula Di Situbondo Bagi Masyarakat}

Letak pabrik gula di Situbando tidak jauh dari pedesaan sehingga masih dapat dijangkau oleh para tenaga kerja dari desa di sekitarnya (Van Der Mandere, 1928:71). Mereka berasal dari lapisan sosial ekonomi yang berbeda. Akan tetapi tidak terpisah dalam kaitan kerja atau produksi. Tata letak pemukiman pabrik gula terlihat kontras. Arsitektur rumah, format maupun fasilitas kediaman bangsa Eropa dengan perkampungan pribumi sangat beda. Komunitas besar (administrateur) dan tuan-tuan kecil (opzichter dan assisten) menempati gedung yang memenuhi peryaratan kesehatan, lengkap dengan segala macam fasilitas. Komunitas Eropa merupakan "enclave" di lingkungan pabrik gula. Homogenitas penduduknya dijaga ketat dan ko-munikasi dengan golongan non-Eropa dibatasi.

Sejak pabrik gula berdiri, bangsa Eropa memegang kebijakan, penanaman modal serta pengelolaan perusahaan. Sebaliknya para buruh dieksploitasi tenaganya untuk penanaman, perawatan dan panen (EConomisch Weekblad Voor NederlandschIndie,1932/1933:36-9). Mereka berasal dari Madura maupun desa di sekitar pabrik gula. Dengan demikian peran tenaga pribumi berada pada lapisan bawah. Hubungan kerja antar kedua lapisan dilakukan oleh perantara, yaitu tenaga pembantu (asisten) dan pengawas (opzichter). Para buruh 
atau kuli, masuk kelompok atau regu diawasi oleh seorang mandor. Beberapa mandor dikoordinir mandor kepala. Mereka diawasi oleh para assisten dan opzichter. Peran pemimpin regu dalam organisasi kerja pabrik gula sangat penting. Oleh karena itu, dia selain berperan sebagai pemimpin unit kerja, juga sekaligus sebagai perantara ke pihak atasannya.

Para buruh industri gula di Situbondo merupakan penduduk desa yang tidak memiliki tanah. Apabila seorang buruh berhasil mendapat kedudukan di pabrik gula, mereka akan menjadi tenaga kerja tetap. Statusnya lebih tinggi dari pada buruh biasa dan berhak menerima fasilitas perawatan kesehatan gratis, bahkan ada juga di antara mereka yang memiliki rumah di lingkungan pabrik gula (Anon, 47-7 dan 59-61). Termasuk tukang kepala sampai tenaga kuli.

Dibukanya banyak pabrik gula di daerah Situbondo menimbulkan masalah terhadap ketenagakerjaan. Kebutuhan buruh dicukupi oleh penduduk lokal. Jumlah tenaga kerja yang disiapkan oleh desa di sekitar pabrik gula tiap tahunnya tidak sama, tergantung lokasi kebun tebu. Pada tahun 1930-an hampir 65\% dari rumah tangga di lingkungan pabrik gula di Situbando, terlibat dalam pekerjaan tersebut. Ketika itu pabrik PG. Soekowidi mempekerjakan buruh sebanyak 20.205 termasuk tukang kepala (Arsip Suiker, Indigo en Cassave, bundel 2374), namun dari jumlah itu masih terhitung sedikit untuk perkebunan tebu yang begitu luas mulai dari masa tanam musim giling. Ketika puncak kesibukan berlangsung, pabrik gula sulit mendapatkan tenaga kerja.

Keberadaan pabrik gula Situbondo berdampak terhadap kehidupan sosial ekonomi penduduk desa. Sementara itu aktivitas sosial masyarakat cukup banyak yang tentunya membutuhkan biaya yang tidak kecil, antara lain sedekah, fitrah, zakat, pesta perkawinan, dan 'bersih desa'; sedangkan penghasilan mereka per bulannya terbatas. Umumnya berasal dari pertanian, dan para pemilik sawah dengan penghasilan 168 gulden per tahun. Para pamong desa penghasilannya 467 gulden per tahun, sedangkan para sikep hanya sebesar 10 sen per harinya atau 36 gulden per tahun (Arsip Index Folio, 1929:961).

Agar kebutuhan sosial bisa terpenuhi, penduduk desa juga bekerja di tempat lain dalam perdagangan, kerajinan atau sebagai buruh. Oleh karena tingkat kebutuhan hidup di desa sangat terbatas, maka perdagangan dan kerajinan hanya memainkan peranan sangat kecil. Dengan demikian, kesempatan menjadi buruh di pabrik gula Situbondo tidak disiasiakan.

Kesempatan kerja yang diberikan oleh pabrik gula dan upah yang dibayarkan di daerah menjadi sumber penghasilan sebagian penduduk Situbondo. Pada tahun 1930-an, jumlah hasil kerja upahan mencapai 950.000 orang (Arsip Het Secretariaat 1932/1933:38). Hal ini berarti bahwa pada musim giling dari bulan April hingga September, setiap harinya rata-rata 5500 buruh direkrut 
untuk penebang tebu, pengangkut, dan penanaman. Para buruh itu menerima upah sebesar 24 sen, sama dengan upah yang biasa diterima sebagai buruh tani di desa. Hanya saja jam kerja di perkebunan tebu lebih panjang, dengan pekerjaan lebih berat.

Di daerah Situbondo, daur rotasi tebu lebih pendek dari pada daerah lain. Tebu ditanam di sawah setiap dua atau tiga tahun sekali. Masa pertumbuhan tebu berlangsung kira-kira satu setengah tahun, maka selama daur dua tahun hanya ada satu kali panen tanaman palawija berusia 3 bulan, seperti jagung, sayur-sayuran atau umbiumbian. Dalam daur tiga tahunan, paling banyak ada dua kali panen padi dengan satu kali panen yang hasilnya rendah dan satu atau dua kali panen tanaman palawija, dengan syarat bila persediaan airnya cukup banyak. Dengan kata lain, $66 \%$ atau $35 \%$ waktu selama musim hujan dipakai untuk menanam tebu, sedangkan $83 \%$ dan 54\% waktu selama musim kering tidak dapat digunakan untuk pertanian rakyat kecil (Arsip Binnenlandsch Bestuur, Bundel 2374).

Seringkali, air tidak disediakan untuk tanaman selain tebu. Di hulu sungai dari pabrik gula ada larangan untuk menyalurkan air dari sungai Sampean atau saluran irigasi selama musim kemarau. Larangan ini membuat petani marah, sehingga sering terjadi pengambilan air atau "pencurian air". Hal itu terjadi karena, bila penduduk menanam palawija, kemudian gagal panen, resikonya, mereka tanggung sendiri. Agar tanamannya tidak kekurangan air, petani terpaksa melakukan tindakan itu. Akan tetapi, di hilir pabrik gula air harus tersedia untuk kebutuhan penduduk, karena lebih 1250 hektar lahan ditanami padi musim kering (Arsip Binnenlandsch Bestuur, Bundel 2374).

Sistem pengairan di daerah aliran sungai Sampean di Distrik Situbondo pada umumnya sangat baik, $90 \%$ lebih dari lahan pertaniannya merupakan sawah berpengairan. Di daerah hilir kali Sampean seluruh lahan sawah dapat diairi secara serentak, baik pada musim hujan maupun musim kemarau. Begitu pula di bagian selatan Sampeyan, lahan sawahnya dapat diairi dengan baik pada musim kemarau. Pada lahan irigasi, lebih dari $80 \%$ digunakan untuk tanaman padi, sedangkan sisanya $20 \%$ dimanfaatkan untuk penanaman tebu (Arsip Binnenlandsch Bestuur, Bundel 2374). Namun demikian, pengaruh produksi tebu terhadap penggunaan lahan di daerah ini teryata lebih besar.

Pada tahun 1930-an, petani selama musim hujan menanam padi dilahanya sebagai tanaman pokok. Tanaman palawija pada umumnya dihasilkan pada musim kemarau sebagai kelanjutan dari penanaman padi atau penanaman tebu. Jenis tanaman palawija terpenting di antaranya jagung, ubi, kayu, ketela rambat, kedelai, kacang tanah dsb. Namun, karena ubi kayu tidak cocok menjadi tanaman giliran dengan padi maka sebagian besar ditanam di tanah kering.

Para petani juga menanam berbagai jenis tanaman lain seperti 
ketimun, terong, cabai, kapas dan tembakau. Namun demikian, berbagai tanaman itu hasilnya masih sedikit. Sementara itu, tanah pekarangan pun ditanami beranekaragam tanaman yang bermanfaat, seperti sayuran, buah-buahan, kelapa, kopi dan nipah yang dapat dipanen sepanjang tahun. Tanamanitu merupakan sumber pendapatan penting bagi penduduk desa yang tidak memiliki tanah.

Sebelum krisis ekonomi berlangsung, kehidupan masyarakat desa di daerah Situbondo cukup dinamis. Perluasan tanaman tebu, dan proyek pengairan Banyuputih, Purbo, Kali Tanggoel dan Bondoyudo, banyak melibatkan masyararakat (Arsip Binnenlandsch Bestuur, Bundel 2374). Perluasan tanaman tebu berakibat munculnya konflik sosial antara pabrik gula dan petani rakyat. Penyelesaian proyek tersebut tahun 1929, sangat berpengaruh terhadap produksi tanaman pangan dan kehidupan petani di daerah itu dan petani setempat. Ketika konflik terjadi, banyak perkebunan tebu dibakar oleh masa (Arsip Verslag, 1926:17). Untuk meringankan ketegangan itu, diperlukan peningkatan efisiensi penggunaan tanah melalui pembangunan fasilitas pengairan, perbaikan mutu lahan dsb. Hal-hal demikian menjadi masalah pokok yang harus diselesaikan demi perkembangan industri gula.

Dampak pabrik gula terhadap masyarakat pedesaan di daerah Situbondo, setiap periodenya selalu berubah. Sebelum terjadi krisis pabrik gula melakukan ekstenifikasi lahan sehingga para penduduk di daerah itu kehilangan tanah pertanian yang produktif, berubah menjadi perkebunan tebu. Persediaan air untuk irigasi sawah di daerah hulu sungai ikut berkurang, sehingga para petani kesulitan mendapatkan air. Namun demikian, penduduk yang tidak memiliki tanah, banyak mendapatkan pekerjaan sebagai buruh di pabrik gula. Selain itu banyak juga penduduk yang ber untung dari sewa tanah. Ketika terjadi krisis, enam dari 9 pabrik gula yang ada di daerah Situbondo tidak produksi. Ribuan buruh, yang berasal dari daerah, setempat dan Madura kehilangan kesempatan kerja.

Industri gula Situbondo mampu menyumbang jutaan gulden kepada pemerintah kolonial Belanda. Hadirnya pabrik gula juga memberi nilai tambah bagi masyarakat di sekitarnya. Ribuan tenaga kerja direkrut dari penduduk setempat. Guna lebih menyatukan dengan masyarakat, sebelum musim giling tiba, pabrikpabrik gula di Situbondo menggelar "pasar malam". Demikian pula, berbagai fasilitas yang dimiliki pabrik gula, bisa dimanfaatkan oleh masyarakat di sekitarnya antara lain berupa sekolah dan rumah sakit (Anon, hlm 41-73).

\section{Pergulaan masa kini}

Tidak efisiennya industri gula masa kini, selain rendahnya produksi hablur, juga karena industri gula menghadapi kendala yang tidak kecil. Sebagai BUMN, struktur kepegawaian industri gula tidak jauh berbeda dengan instansi pemerintah. Struktur 
kepegawaiannya tambun, sumber daya manusia yang terlibat cukup besar. Rekrutmen karyawan tidak berdasar analisis kebutuhan melainkan pada bagaimana menampung tenaga kerja melalui berbagai cara. Akibatnya, industri gula terbebani biaya overhead yang tinggi. Selain itu mesin-mesin PG banyak yang tua/kuno, perlu rehabilitasi dan perawatan. Demikian pula, pabrik gula berperilaku sebagai pabrik gula pada masa kolonial. Meskipun petani menjerit karena pendapatannya rendah, pabrik gula terkesan eksklusif dengan manajemen dan pola hidup yang feodalistik.

Didirikannya pabrik gula baru dengan manajemen profesional, merubah peta industri gula masa kini. Perusahaan ditangani dengan manajemen profesional, dan proses produksi gula dikelola dengan orientasi bisnis murni. Terlihat pada PG-PG swasta besar seperti PT Gunung Madu, PT Gula Putih Mataram, PT Sweet dan Indo Lampung. Mereka beroperasi memanfaatkan lahan HGU sehingga perusahaan tidak kesulitan berurusan dengan petani pemilik lahan. Pengolahan lahan dilakukan dengan alat berat, pabriknya relatif baru, dan jumlah karyawan sesuai kebutuhan. Mengikuti manajemen agrobisnis yang ideal, biaya produksi dapat ditekan serendah mungkin. Bahkan, hanya separuh dari biaya produksi PG BUMN, dan sanggup bersaing dengan gula impor.

Aktivitas impor gula diatur melalui Surat Keputusan Menteri Perindustrian dan Perdagangan (SK No. 643/MPP/Kep/9/2002) tentang tataniaga Impor Gula (TIG) telah menimbulkan reaksi dan hasil akhir yang beragam. Kebijakan tataniaga itu memberikan privilis kepada importir produsen (IP) untuk mengimpor gula mentah (raw sugar) dan kepada importir terdaftar (IT) untuk mengimpor gula putih (white sugar). Mereka adalah perkebunan gula yang memiliki perolehan bahan baku 75 persen berasal dari petani. Perusahaan perkebunan yang memenuhi kualifikasi sebagai IT adalah empat Badan Usaha Milik Negara (BUMN) yang masuk kualifikasi, yaitu: PT Perkebunan Nusantara (PTPN) IX, PTPN X, PTPN XI, dan PT Rajawali Nusantara Indonesia (PT RNI)(Bustanul Arifin, 1998:5).

Kebijakan impor gula berpengaruh terhadap kondisi pergulaan nasional. Target swasembada gula tak tercapai terlihat kuat. Indikator utama, produksi tak kunjung beranjak naik mendekati sasaran 5,7 juta ton gula Kristal putih (GKP) atau disebut gula pasir. Produksi gula pasir berbasis tebu dalam negeri stagnan tiga tahun terakhir. Produksi gula pasir dalam negeri sejak tahun 2003 sebesar 1,632 juta ton melonjak drastis menjadi 2,052 juta ton tahun 2004 (Ninuk M. Pambudy dan Hermas E Prabowo, 2011: 45) Peningkatan terjadi karena pemerintah menerapkan program bantuan bagi petani untuk bongkar tanaman lama (ratoon) dan mengganti dengan bibit baru.

Puncak produksi tertinggi tercapai tahun 2008, yaitu 2,668 juta ton, tetapi turun menjadi 2,3 juta ton tahun 2009, 2,214 juta ton tahun 2010, dan tahun ini diperkirakan 
paling tinggi 2,57 juta ton, lebih rendah dari target awal 2,73 juta ton (Ninuk M. Pambudy dan Hermas E Prabowo, 2011: 45) Penyebabnya, rendemen (kadar gula dalam batang tebu yang dapat diekstraksi di pabrik) turun dari perkiraan awal 7,6 persen menjadi 7,4 persen. Sebaliknya, impor gula justru naik terus. Dari periode 2005-2010, besar kenaikan 9,8 persen. Dewan Gula Indonesia (DGI) mencatat, impor tahun 2003 sebesar 2.456 .642 ton, lalu menjadi 3.622.738 ton pada 2010 atau 62 persen dari total gula dalam negeri (Ninuk M. Pambudy dan Hermas E Prabowo, 2011: 45). Tidak tercapainya swasembada gula karena konsistensi pemerintah dalam program tersebut masih lemah.

'Dalam empat tahun terakhir, ekonomi pergulaan Indonesia semakin kompleks. Restrukturisasi industri gula domestik diikuti tumbuhnya industri gula rafinasi (refinery) yang cepat. Industri gula rafinisasi memiliki pangsa pasar berbeda dengan industri gula putih biasa. Pasarnya lebih banyak tertuju pada industri makanan dan minuman di dalam negeri. Investasi baru dan pengembangan industri gula rafinasi akan menjadi peluang besar bagi peningkatan kapasitas industri domestik dan penyerapan lapangan kerja.

Peraturan Menteri Perdagangan nomor 111 Tahun 2009 mengatur distribusi gula rafinasi. Penyaluran gula rafinasi tidak lagi langsung ke industri pengguna, melainkan melalui distributor. Pasokan gula rafinasi pun melonjak.
Bila tahun 2005 hanya 759.708 ton dan 2006 sebanyak 1,1 juta ton, tahun 2009 naik menjadi 2,03 juta ton (Hermas E Prabowo, 2011:46).

Kebijakan tataniaga gula sebaiknya berkontribusi meningkatkan pendapatan petani tebu (Khudori 2005). Nahdodin dan Rusmanto (2008) bahkan secara eksplisit menyebutkan bahwa kebijakan tataniaga gula cukup efektif melindungi produsen gula berdasarkan indikator harga yang berlaku. Kebijakan impor itu tidak menimbulkan monopoli pemasaran sehingga margin pemasaran tidak membesar dan tidak merugikan konsumen. Namun demikian, kebijakan tataniaga gula dalam negeri tersebut belum dapat memberi perlindungan pada produsen gula (tebu) dari distorsi harga gula dunia. Pada intinya, produsen gula (tebu) dalam negeri masih tertekan oleh perilaku produsen gula yang lebih protektif.

Pada sisi lain, kebijakan itu juga memberikan peluang bagi pengembangan industri gula rafinasi. Bukan dikonsumsi untuk rumah tangga melainkan sebagai pemutih gula mentah impor. SK 643/2002 antara lain menjelaskan bahwa gula mentah dan gula rafinasi (refined sugar) yang diimpor oleh importir produsen (IP) hanya digunakan sebagai bahan baku untuk proses produksi pengolahan gula, dan tidak diperdagangkan (Bustanul Arifin, 1998:6).

Persoalan swasembada gula ada mulai dari hulu, yakni budidaya pertanian hingga hilir, yaitu tataniaga. Di hulu, tanaman tebu banyak merupakan tanaman keprasan sehingga rendemennya rendah. 
Program bantuan bongkar ratoon terakhir dilakukan tahun 2003. Setelah itu tidak menjadi prioritas. Pusat Penelitian Perkebunan Gula Indonesia memiliki bibit unggul yang potensi rendemennya mencapai 12 persen dan tebu 113,1 ton per hektar atau setara 13,7 ton gula pasir. Akan tetapi petani harus mendapat kepastian bahwa pabrik gula (PG) bekerja efisien sehingga rendemen akhir tinggi.

Efisiensi pabrik sangat berpengaruh terhadap rendemen gula pasir dan kualitasnya. Hingga 2010 ada 61 PG dengan total kapasitas 225.018 TCD dan areal 418.259 hektar serta 8 PG rafinasi dengan total kapasitas 3,2 juta ton gula Kristal rafinasi pertahun.

Sebagian besar PG tersebut, terutama milik BUMN, usianya tua yang sebagian merupakan peninggalan Belanda. Akibatnya rendemen pun rendah. Target rendemen tahun 2010 sebesar 8 persen, hanya mencapai 7,4 persen (Hermas E Prabowo, 2011:46). Untuk itu PG-PG tersebut jelas butuh revitalisasi, memodernisasi mesin yang tua. Jika memungkinkan menurut Yusuf Kalla membangun 15-20 PG baru (Suhartono, 2011:47). Kini, program revitalisasi PG terhambat oleh kebijakan impor gula rafinasi dan gula mentah bahan baku gula rafinasi. Impor gula rafinasi langsung oleh industri makanan dan minuman (mamin) 715.000 ton, lalu ada impor gula mentah oleh PG yang kapasitasnya tak terpenuhi dari tebu sebanyak 448.000 ton, dan produksi gula rafinasi berbahan baku gula mentah sebesar 1,441 juta ton.

Kebijakan impor tersebut membuat stok gula berlebih. Kelebihannya mencapai 900.000 ton, menjadi cadangan tahun berikut. Harga lalu jatuh. Kenyataan ini berpengaruh terhadap program revitalisasi pabrik. Bank ragu menyalurkan kredit yang umumnya harus kembali dalam delapan tahun. Akibatnya program revitalisasi periode 2007-2009 dengan dana $R p$ 4,5 triliun hanya bisa menyerap $\mathrm{Rp} 0,5$ triliun (Ninuk M. Pambudy dan Hermas E Prabowo, 2011: 45).

\section{Penutup}

Industri gula merupakan industri manufaktur yang berorientasi ekspor dan bermodal asing. Ketika depresi ekonomi, agro industri ini paling parah terkena dampaknya. Oleh karena harga gula di pasar internasional terus menurun dan nilai kurs $\mathrm{f}$ (gulden) terhadap standar emas melemah. Akibatnya, industri gula yang ada di Situbondo kesulitan membayar hutangnya pada investor. Ketika itu, PG-PG melakukan penghematan terhadap berbagai pos pengeluaran.

Dengan munculnya berbagai permasalahan dalam perusahaan, pihak manajemen melakukan tindakan ekonomis. Manajemen strategi yang dilakukan antara lain peningkatan produksi dan Produktivitas, pengurangan tenaga kerja, penjualan aktiva serta saham yang dimiliki perusahaan. Demikian pula dimergernya beberapa pabrik gula oleh per- 
usahaan yang sama. Pabrik gula tersebut adalah PG. Panji, PG. Olean, PG. Prajekan, PG. Buduan, dan PG. Semboro. Hadirnya PG-PG di Situbondo, selain menimbulkan dampak positif bagi masyarakat di sekitarnya, juga berdampak negatif bagi sosial ekonomi mereka. Terserapnya ribuan tenaga kerja oleh pabrik gula merupakan salah satu indikator. Dampak negatif yang muncul berupa hilangnya lahan pertanian, menjadi perkebunan tebu. Hal ini memicu konflik sosial di masyarakat, pembakaran puluhan hektar perkebunan tebu merupakan salah satu contohnya.

Produktivitas industri gula saat ini rendah karena terbebani biaya overhead yang tinggi. Mesinmesin pabrik gula banyak yang tua/kuno, serta manajemen pabrik gula masih terwarisi masa kolonial. Pabrik gula terkesan eksklusif dengan manajemen dan pola hidup yang feodalistik. Selain tata niaga gula yang tak tertata, koordinasi juga tidak berjalan. Impor gula mentah dan merembesnya gula rafinasi ke pasar umum semakin memperburuk keadaan. Padahal, selama ini, petani dan industri gula hanya mengandalkan dana sendiri untuk revitalisasi sehingga tak berkembang. Agar swasembada gula tercapai tak ada jalan lain kecuali menghentikan impor serta membantu pengadaan bibit tebu dan peningkatan revitalisasi pabrik gula. 


\section{Daftar Pustaka Sumber-sumber arsip}

Achief voor de Suikerindustrie in Nederlandsch-Indie 31ste Jaargang $19231 e$ Deel. Het Algemeen Syndicaat Van Suikerfabrikanten in Ned Indie.

Achief voor de Suikerindustrie in Nederlandsch-Indie 37ste Jaargang 1929 3e Deel. Mededelingen van het Proefstation. Soerabaja: NV. Boekhandel En Drukkerij v/h H.Van Ingen.

Achief voor de Suikerindustrie in Nederlandsch-Indie 42ste Jaargang 1934 1e Deel. Het Algemeen Syndicaat Van Suikerfabrikanten in Ned Indie.

Achief voor de Suikerindustrie in Nederlandsch-Indie 1ste Jaargang 1940 en Jaargang 1941-1942. Soerabaja: NV. Boekhandel En Drukkerij v/h H.Van Ingen.

Proefstation Voor De Java-Suikerindustrie Verhandelingen Voor De Leden Jaargang 1935, 1937 En Jaargang 1940. Soerabaja: Druk. H. Van Ingen.

Verslag: Van Het Algemeen Syndicaat Van Suikerfabrikanten in Ned-Indie Over Het 32e Jaar, 1926.

Verslag: Van Het Algemeen Syndicaat Van Suikerfabrikanten in Ned-Indie Over Het 39e, 40e En 41e Vereenigings Jaar, 1933-1935.

Verslag: Van Het Algemeen Syndicaat Van Suikerfabrikanten in Ned-Indie Over Het 44e Vereenigings Jaar, 1938
Staatsblad Van Nederlandsch-Indie 1933 No. 351. Accijnzen Suiker. Regelling van de heffing en vezekering van den suikeraccijns ("Suikeraccijns ordonnantie 1933")

Staatsblad Van Nederlandsch-Indie, 1941 No 46 Binnenlandsch Bestuur. Ost-Java. hlm 1-21

Naamlooze Vennootschap Suiker cultuur Maatschappij Wonolangan Verslag Over Het Boekjaar 1925, 1926, 1927, 1928, 1929, 1930, 1931, 1932, 1933, 1934, 1935, 1936.

\section{Buku-buku}

Abraham Nurcahyo, 1999. "Manajemen Pabrik Gula Di Situbondo Dalam Menghadapi Krisis 1925-1941." Tesis. Yogyakarta: Program Pasca Sarjana UGM.

A.T. Birowo, et.al. (Penyunting)1992 Perkebunan Gula seri Manajemen Usaha Perkebunan. Yogyakarta: Lembaga Pendidikan perkebunan.

Bustanul Arifin. 2007. Diagnosis Ekonomi Politik Pangan dan Pertanian. Jakarta: Penerbit Rajawali Pers.

2008. Economic Review No. 211 Maret 2008

Boomgaard, Peter Changing Economy in Indonesia Volume 13 Weges 1820-1940, (Amster-dam: Royal Tropical Insti-tute, 1992). 119-20.

Elson R.E. 1984. Javanese Peasants and The Colonial Sugar Industry: Impact and Change in an East Java 
Residency1830-1940.

Singapore:

Ox-ford

University Press.

Hermas E Prabowo. 2011 "Gurita Gula Rafinasi." Kompas, 29 Juli 2011.

Hernomo Budhisantoso et. al. edt.1997. Indonesian Sugar Research Innstitute one hundred and ten years of service July 9, 1887 - 1997, Pasuruan: P3GI, 1997

H.C. Prinsen Geerligs, 1934. " The Sugar Situation in 1933" Economic Bulletin of Netherlands India Vol 1 No 21 Januari 1934. Hlm 353356.

Khudori. 2005. Gula Rasa Neoliberal-isme: Pergumulan Empat Abad Industri Gula. Jakarta: Pustaka LP3ES.

Knight, G.R. 1993. Colonial Production in Provincial Java The sugar Industry in Pekalongan-Tegal 18001942. Amsterdam: VU Unversity Press.

Lock, Dennis dan Farrow,Nigel, 1999.Manajemen Umum Buku I: The Gower Hanbook of Management. Jakarta: Elex Media Komputindo.

Loekman Soetrisno. 1980. "The Sugar Industry and Rural Development: The Impact of Cane Cultivation for Export on Rural Java 1830-1934" Diser- tasi New York: Cornell University tasi New York: Cornell University

Mubyarto dan Daryanti, 1991. Gula: Kajian Sosial Ekonomi. Yogyakarta: aditya Media.

Nahdodin dan Joko Roesmanto. 2007. "Evaluasi Terhadap Kinerja Surat Keputusan Menteri Perindustrian dan Perdagangan Nomor 643/Mpp/ Kep/IX/2002. Pasuruan: Pusat Penelitian Perkebunan Gula Indonesia (P3GI).

Ninuk M. Pambudy dan Hermas E Prabowo. 2011. "Menagih Janji Swasembada Gula 2014" Kompas Jum'at, 29 Juli 2011

Sartono Kartodirdjo, dkk. 1978. Memori Serah Jabatan 19211930. Jakarta: Arsip Nasional Republik Indonesia.

Simatupang, A. Rachman dan Ley Pelitasari. 1999. "Gula dalam Kebijakan Pangan Nasional analisis Historis". Dalam Sawit. H. P Suharno dan A. Rachman. Ekonomi Gula di Indonesia kerjasama Bulog dan IPB. Bogor: IPB. Hlm. 481-545.

Sondang P. Siagian. 2001. Manajemen Sratejik. Jakarta: Bumi Akara.

Suhartono. 2011. "Revitalisasi: Terlambat Mulai, Repot Belakangan." Kompas, 29 Juli 2011.

Supriyono, RA. 1986. Manajemen Strategi dan Kebijaksanaan Bisnis. Yogyakarta: BPFE. 